\title{
Economic Growth and Investment in the Arab World
}

\author{
by \\ Xavier Sala-i-Martin, Columbia University, NBER and UPF \\ Elsa V. Artadi, Harvard University
}

May, 2003

\begin{abstract}
:
This paper analyses the economic growth performance in the Arab world over the last forty years. The Arab world has managed to reduce poverty performance despite its relatively disappointing growth performance. We relate this poor performance of both oil and non-oil producers to investment. Contrary to widespread belief, we do not find evidence that low quantity of investment is the main of low growth. The decline in the investment rate followed rather than preceded the reduction in the aggregate growth rate. We conclude that the low quality of investment projects is the key determinant of growth. The excessive reliance on public investment, the low quality of financial institutions, the bad business environment (due to political and social instability and to excessive public intervention and overregulation) and the low quality of human capital are important determinants of systematically unproductive investment decisions and, thus, low economic growth.
\end{abstract}

Keywords: Economic Growth, Investment, the Arab World.

JEL Classification: o0, o5.

We thank Oussama Kanaan and Nuri Erbas for comments and Claudia Canals for research assistance. This paper was prepared for the Arab Competitiveness Report of the World Economic Forum. 


\section{Growth}

The growth performance of the Arab World over the last twenty years is disappointing.

Figure 1 displays a measure of "Arab World" GDP per capita between 1960 and 2000. ${ }^{1}$ After increasing at rapid rates between 1963 and 1980, GDP per capita stagnated over the following two decades. In fact, GDP per capita in the region as a whole was lower in the year 2000 than in 1980 . The huge decline of the early 1980s led to a very moderate recovery that has not yet helped the region to reach the income levels of 1980 . Of course, not all economies within the Arab world behave exactly in the same way. For example, whereas the pattern of GDP per capita for oil-producing economies is similar to that of the group as a whole (the level is slightly higher for the oil countries than for the average country in the region, but the pattern over time is virtually identical), the non-oil producing countries grew almost continuously between 1960 and 2000 (see also Figure 1) $)^{2}$. The rate at which GDP per capita increased, however, also seemed to slow down after 1980.

${ }^{1}$ The Arab World GDP per capita is constructed aggregating the World Bank s or the Summers-Heston-Aten (2002) PPP-adjusted GDP data for each country and dividing it by aggregate population. Since the data are measured in PPP-adjusted units, it is strictly comparable across countries and, therefore, can be aggregated in principle. The countries used to construct this measure of Arab World GDP are: Algeria, Egypt, Kuwait, Oman, Saudi Arabia, Mauritania, Morocco, Syria, Tunisia, Comoros and Jordan. Lebanon, Libya, the West Bank and Gaza Strip, Bahrain, Qatar, UAE, Iraq and Yemen have been excluded because of data limitations. For example, there is very little information available on the performance of the UAE economy. In fact, the Central Bank published price-adjusted real GDP figures for the first time in 2000. Iraq's GDP data "disappeared" after the Gulf war.

2 Oil producers are Algeria, Egypt, Kuwait, Oman, and Saudi Arabia. The rest of the Arab countries are non-oil producers. 


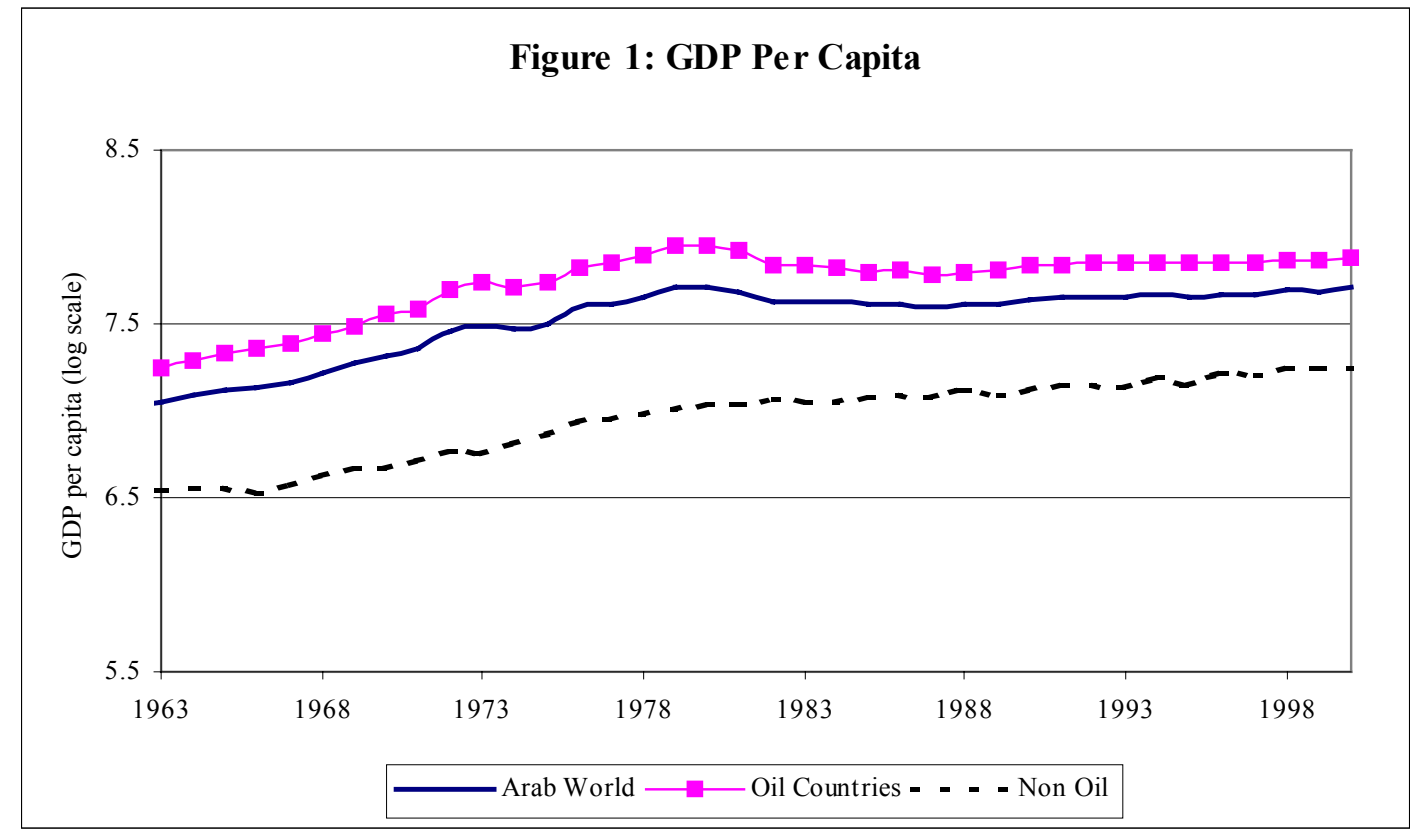

The evolution of the growth rates for the Arab world and its decomposition between oil and non-oil producing countries is displayed in Figure 2. The first thing to notice is that the annual growth rate is highly volatile. The volatility is larger for the oil countries, which shows that the growth rate depends, at least in the short run, on oil prices.

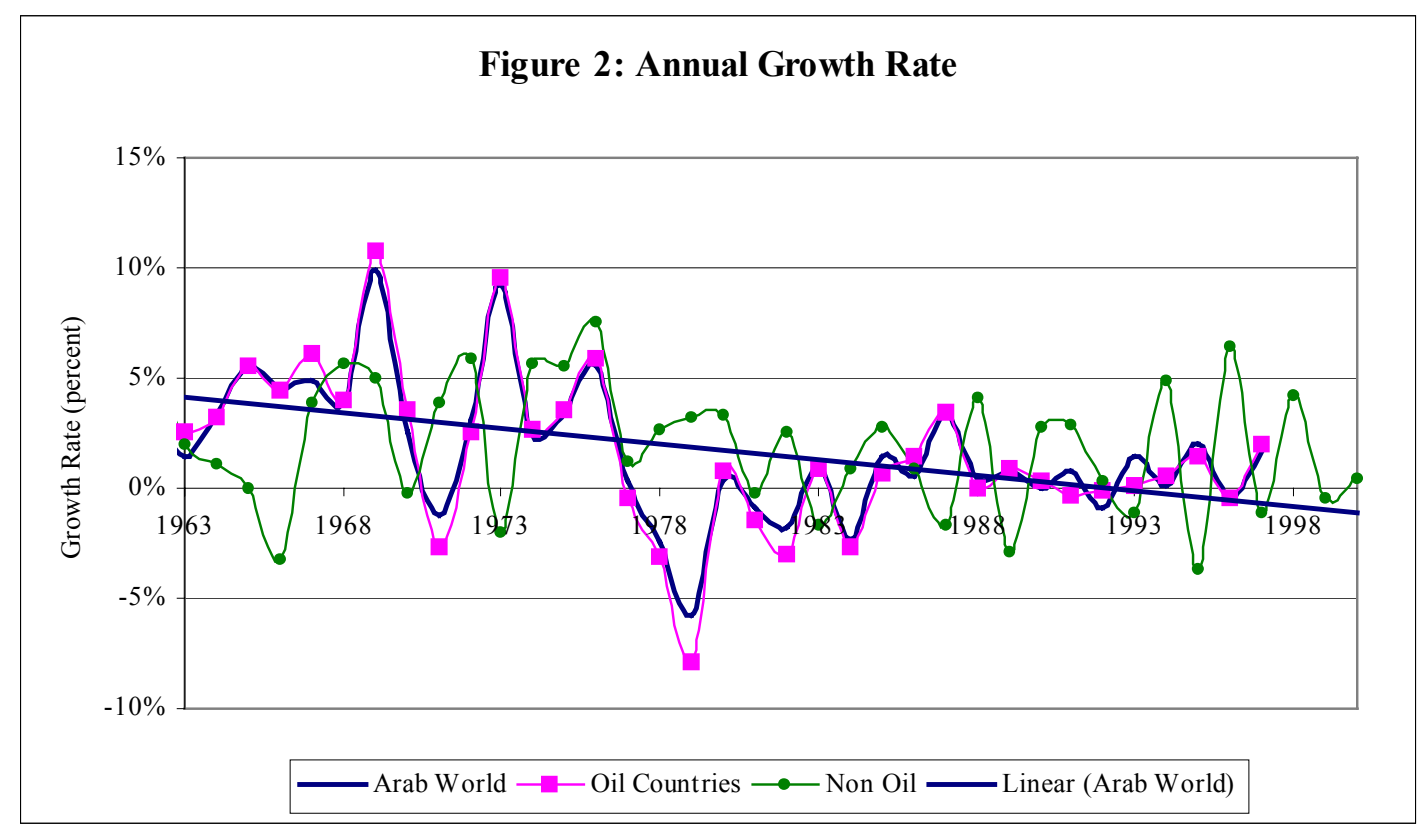


The short-term volatility, however, masks some well defined medium and long-term trends. For example, if we add a linear trend line to Figure 2, we see that it is negativelysloped, which suggests that the growth rate has had a tendency to decline over time. The negative trend of the growth rate over time applies equally to the oil and non-oil producing countries.

Figure 3 decomposes the annual growth rates into averages for five well-defined periods: the pre-oil-shock period (1963-1973), the oil-shock period (1974-1980), the period of steep decline in oil prices (1981-1985), the second half of the 1980s (1986-1990) and the 1990s (1991-2000). We notice that the annual growth rate of per capita GDP for the Arab region as a whole between 1963 and 1973 was well above 4\%. The growth rate declined slightly to just above 3\% between 1974 and 1980. The growth rate was negative $2 \%$ between 1980 and 1985, and it never recovered the levels of the 1960s: the rate was below 1\% during the rest of the 1980s and the 1990s.

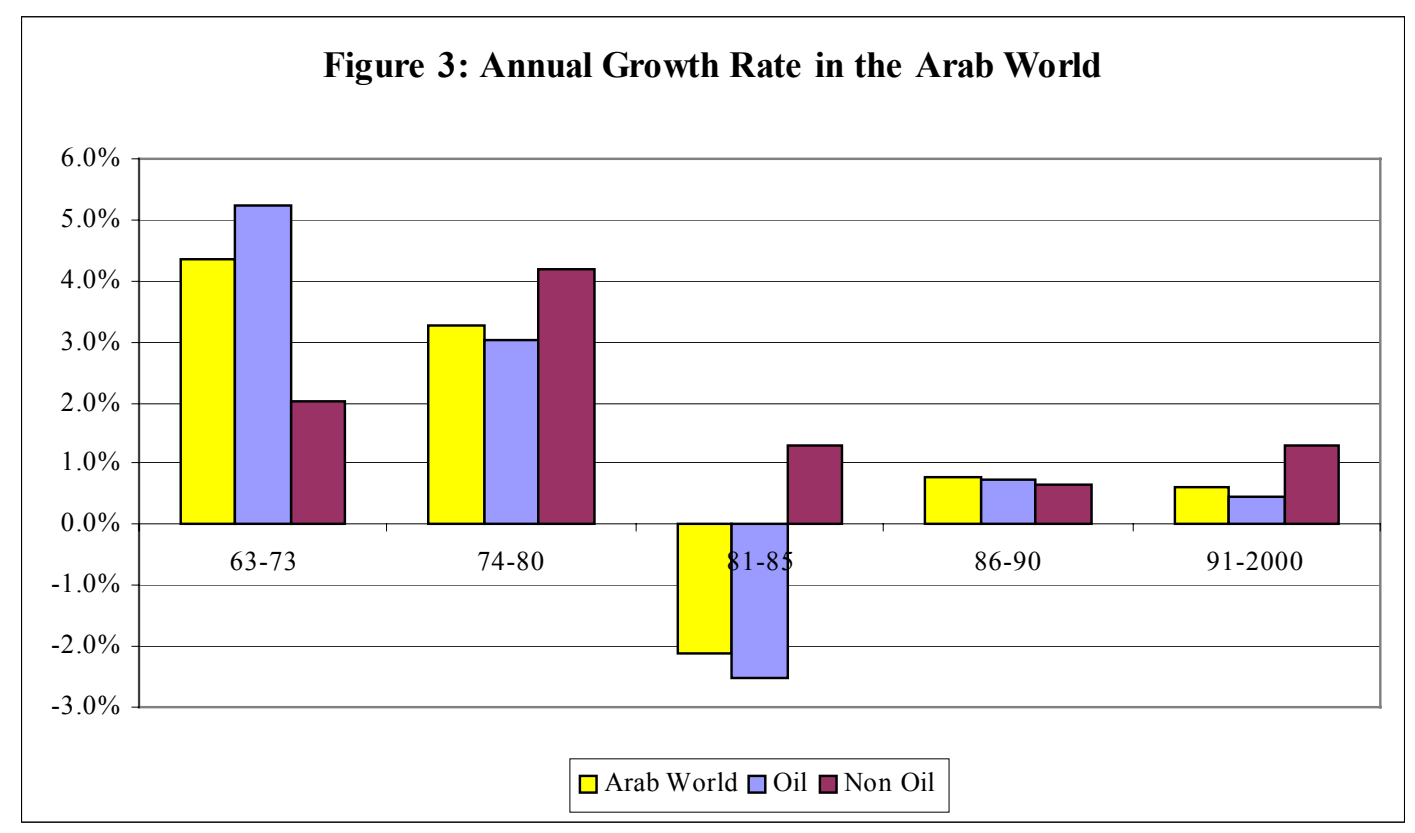

As it was the case for the level of GDP per capita, the behavior of the growth rate was 
not uniform across all the countries in the group. For example, between 1981 and 1985, the growth rate for oil producers was negative whereas that of the non-oil producers was slightly positive (given the superior weight of the oil-producers in overall Arab GDP, the aggregate growth rate for the region ended up being negative). Not surprisingly the growth performance of the oil economies is vastly superior during the second half of the 1970s (when oil prices were high) and vastly inferior during the first half of the 1980s (when oil prices declined). In fact, the growth rate for the oil economies during this period was consistently lower than that of the non-oil countries, although neither of them was very high. Despite these differences, he medium-term behavior of growth rate is similar for oil and non-oil economies: the extraordinary growth rates of the 1960s disappeared after the first oil shock.

The yearly correlations between each country's growth rate and the aggregate growth rate for the region are very low for some of the countries, which indicates that the short-term business cycle for different Arab countries is not highly synchronized. However, when we break-down the period into five medium-term subperiods we see that similar patterns arise.

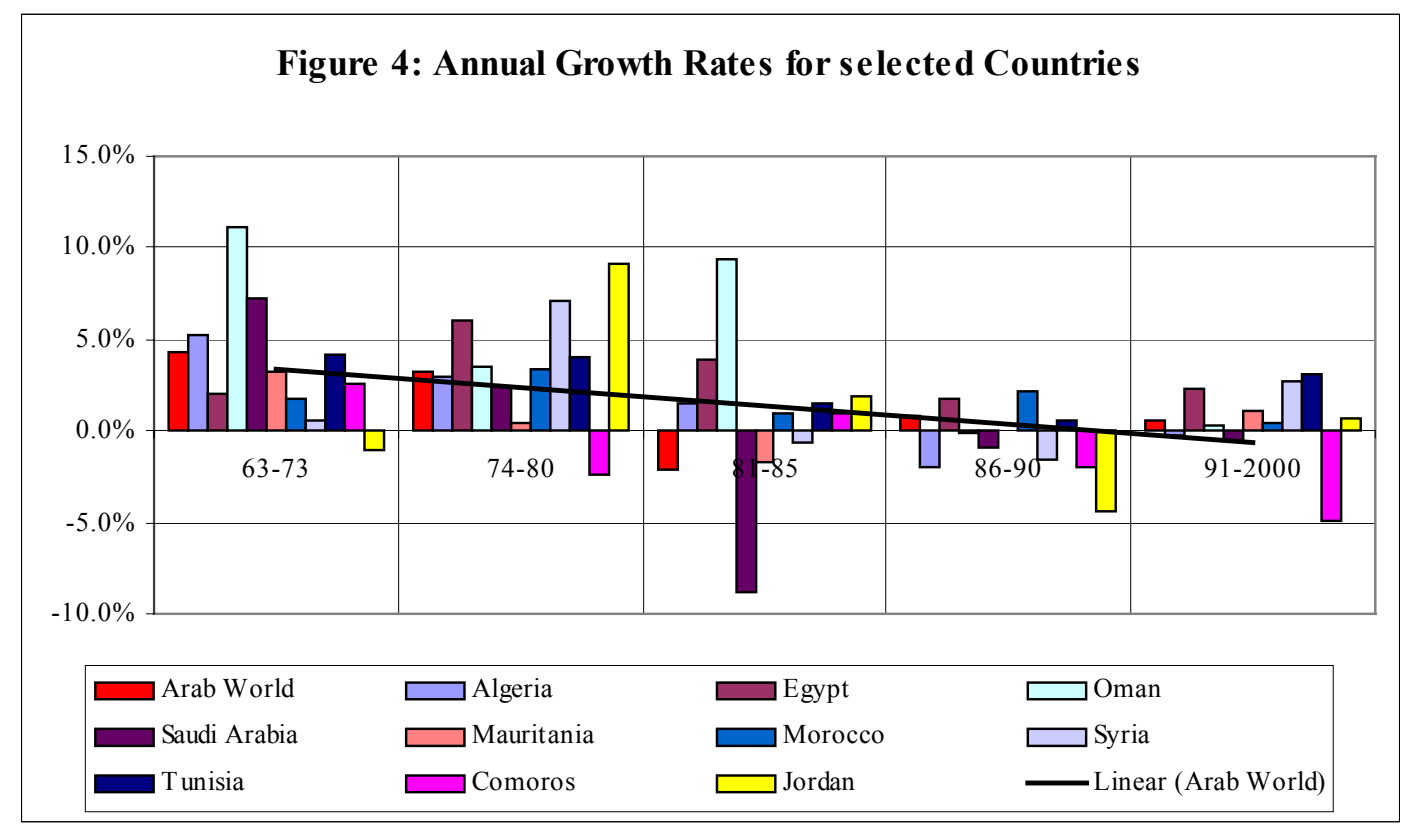


Figure 4 shows the growth rates for the same five superiods defined above for a sample of 10 Arab countries (plus the aggregate Arab world numbers displayed in Figure 3). The growth rates are certainly not the same for every country, but the overall pattern is very similar: large growth rates for the two initial periods, a substantial reduction in the early 1980s (Oman was an exception that was more than offset by the large negative growth rate of Saudi Arabia), and very small growth rates across the board for the second half of the 1980s and 1990s. The overall trend for the growth rates is clearly negative.

In sum, despite that the Arab world displays substantial heterogeneity in its economic growth performance, there is a common behavior that needs to be analyzed: the large growth rates of the 1960s and 1970s disappeared after 1980. For some countries, the growth rate became negative on average, for some countries it declined but remained positive. Overall, however, we can say that the growth performance of the Arab world after 1980 was disappointing across the board.

\section{Growth and the Distribution of Income and Poverty}

The slowdown of the growth process has very important implications for human welfare. For example, positive growth tends to increase the income of most social groups and "shift" the distribution of income to the right. Figure 5 estimates the distribution of income for the Arab region for selected years between 1970 and 1998 using the methodology developed by Sala-i-Martin (2002). We note that the distribution improved substantially during the 1970s. Growth led to improvements in the level of income for the majority of the population, rich and poor. We see that the "area under the distribution" and to the left of the one-dollar-a-day line, that is, the "poverty rate" decreased substantially during this period. As the region's growth rate slowed down, so did the improvement in the income distribution (we 
see in Figure 5 that, between 1980 and 1998, the distribution does not move much to the right). Of course this means that poverty rates did not decline much over the period of slow growth.

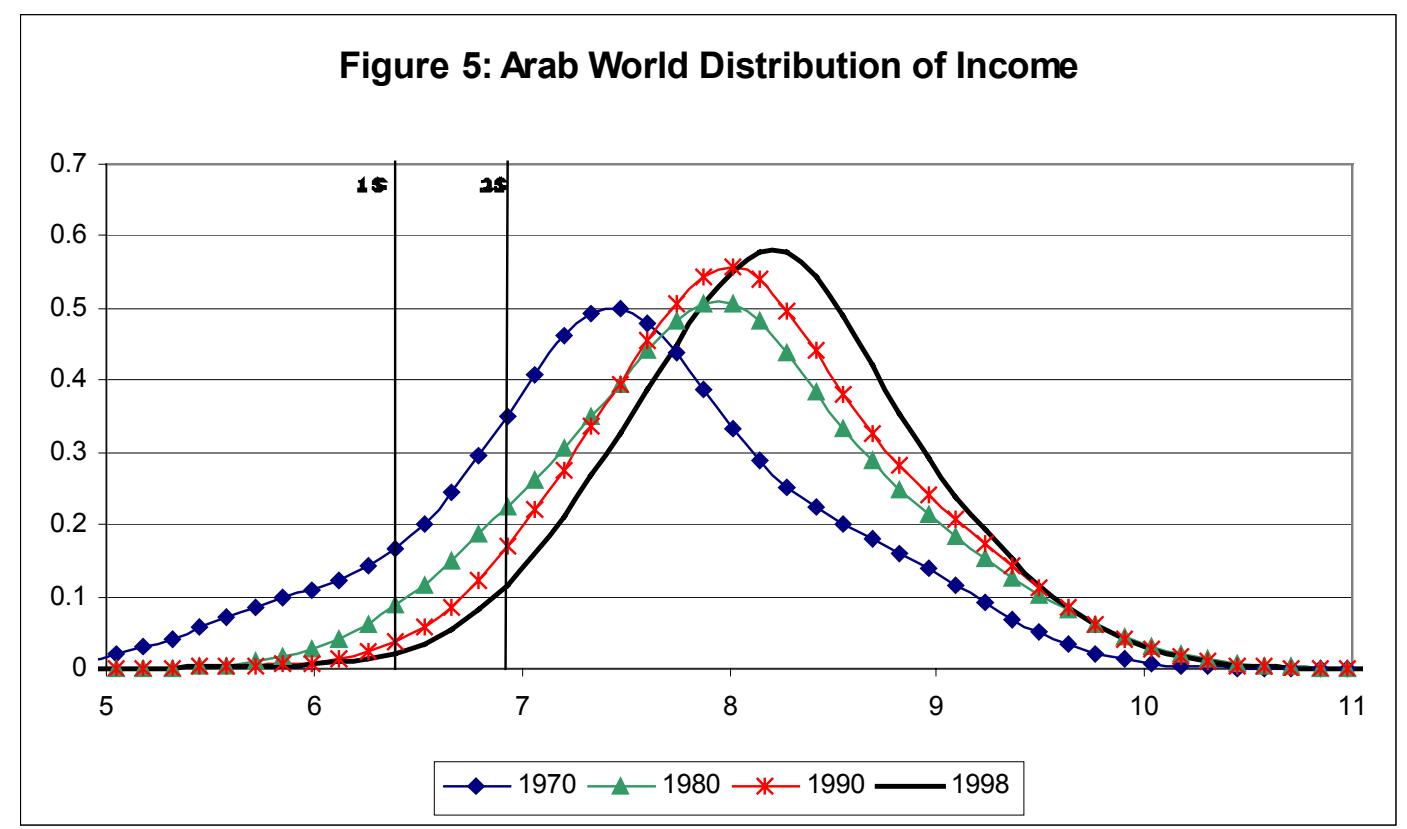

Over the last two decades, the world has witnessed spectacular reductions of poverty rates, thanks to the extraordinary growth performances of some of the largest economies of the planet: China, India and Indonesia. ${ }^{3}$ Figure 6 displays the poverty rates for the Arab world. We see that during the "high growth rate years" of the 1970s, the Arab region witnessed a substantial reduction in poverty rates. The fraction of the population living with less than a dollar a day ${ }^{4}$ went from $11 \%$ in 1970 to $2.4 \%$ in 1980 . The fraction living with less

3 See Sala-I-Martin (2002).

4 The original definition of absolute is due to Ravallion et. al (1991). These researchers used "perceptions of poverty" in the poorest countries to place the poverty line at $\$ 31$ per month. Later, the definition was changed to $\$ 30.42$, and it then was rounded off to $\$ 1$ per day. The $\$ 1 /$ day line was later adopted by the World Bank as the "official" definition of"absolute poverty". Another poverty line appeared in the literature that doubled the original figure to two dollars per day. We use both definitions in this paper. 
than two dollars a day decreased from $30 \%$ in 1970 to $14 \%$ in 1980 . The rapid reduction in poverty rates slowed down dramatically after 1980, when the aggregate growth rates also slowed down. By 1998, \$1/day poverty rates was still 1\% (not much of change since 1980) and the $\$ 2 /$ day rate was still above $5 \%$.

The Arab world has poverty levels that are substantially lower than those of countries with similar levels of income. There are various reasons for that. One is that the public system in the Arab world has constructed relatively effective safety nets as they try to maintain social cohesion and an egalitarian society. Another reason is that Arab countries are marked by an important cohesive system of private social responsibility under which families provide help to their members during hard times and income is redistributed through a religious charitable system. The dual Islamic practices of zakat and sadaqa encourage the rich members of society to donate a percentage of their income and wealth to the poor. Zakat fixes the donations to $2.5 \%$ of annual earnings. Zadaqa allows some larger flexibility to the donor, but it can amount to substantial sums. Overall, the sums of money collected by charitable organizations to redistribute income and to deal with poverty can be estimated to amount to large sums of money. All of this explains why poverty rates in the Arab world are small relative to its income levels. However, Figures 5 and 6 make it clear that the best way to reduce poverty over time is to increase the growth rate of the economy: poverty declined substantially over the period of high growth and progress slowed down significantly during the period of low growth. From a welfare point of view, therefore, one of the key economic questions is: why has the Arab world not grown much after 1980? 


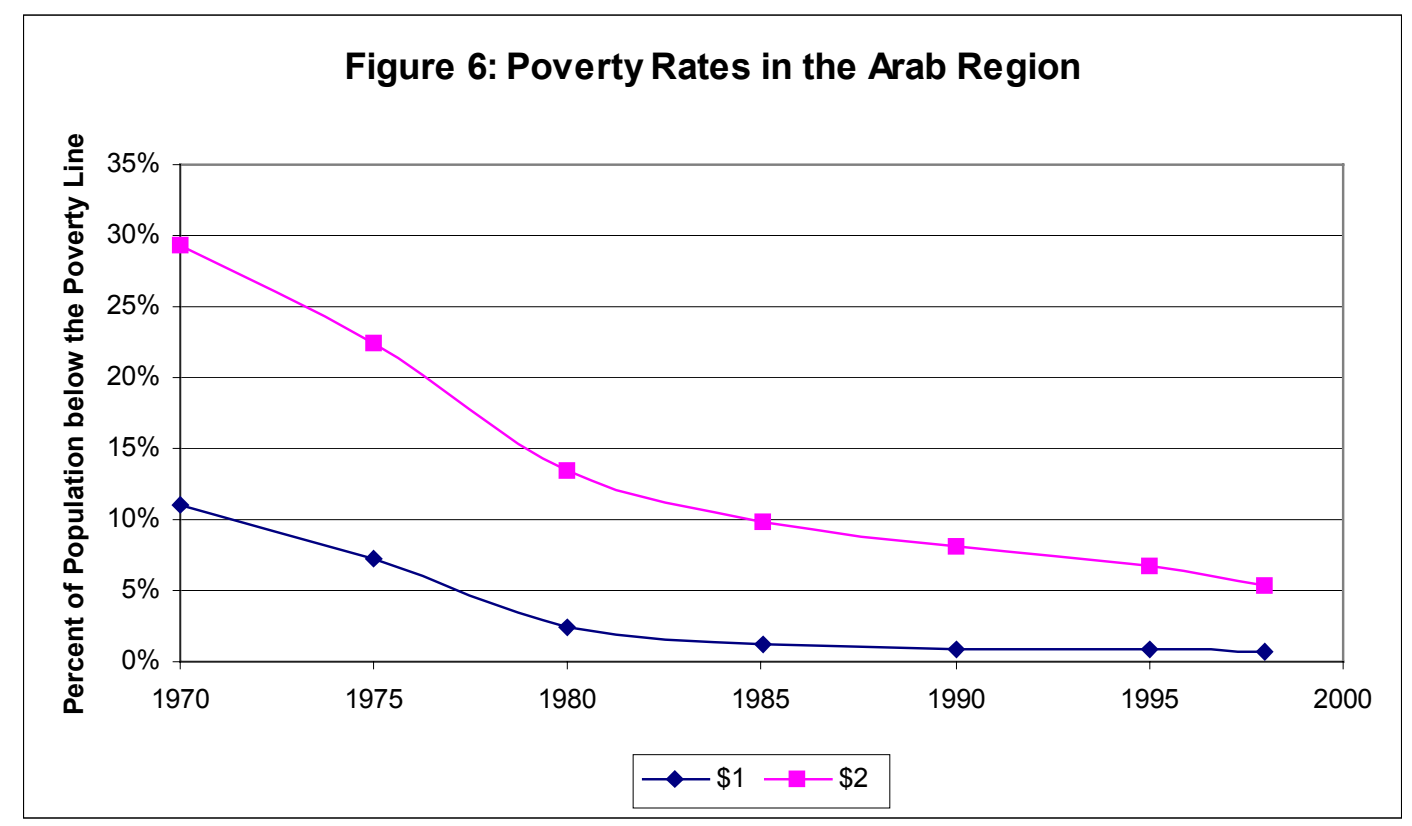

\section{Investment}

The first answer economists tend to give when exploring the economic success or failure of a country or an economic region is that the key determinant of economic growth is the investment rate: countries that grow fast are countries that invest a substantial fraction of their GDP and countries that fail to grow are countries that fail to invest. This explanation is partly based on economic theory. After all, the basic old neoclassical growth model of Solow (1956) and Swan (1956) predicts that one of the key determinants of the growth is the investment rate. Figure 7, however, shows that investment rates in the Arab world are not particularly low. The average investment rate over the period $1974-2000$ is $24.6 \%$, a rate larger than that of the OECD economies $(22.9 \%)$ and only slightly smaller than that of the successful economies, some observers call them miraculous economies, of East Asia (29.9\%). 


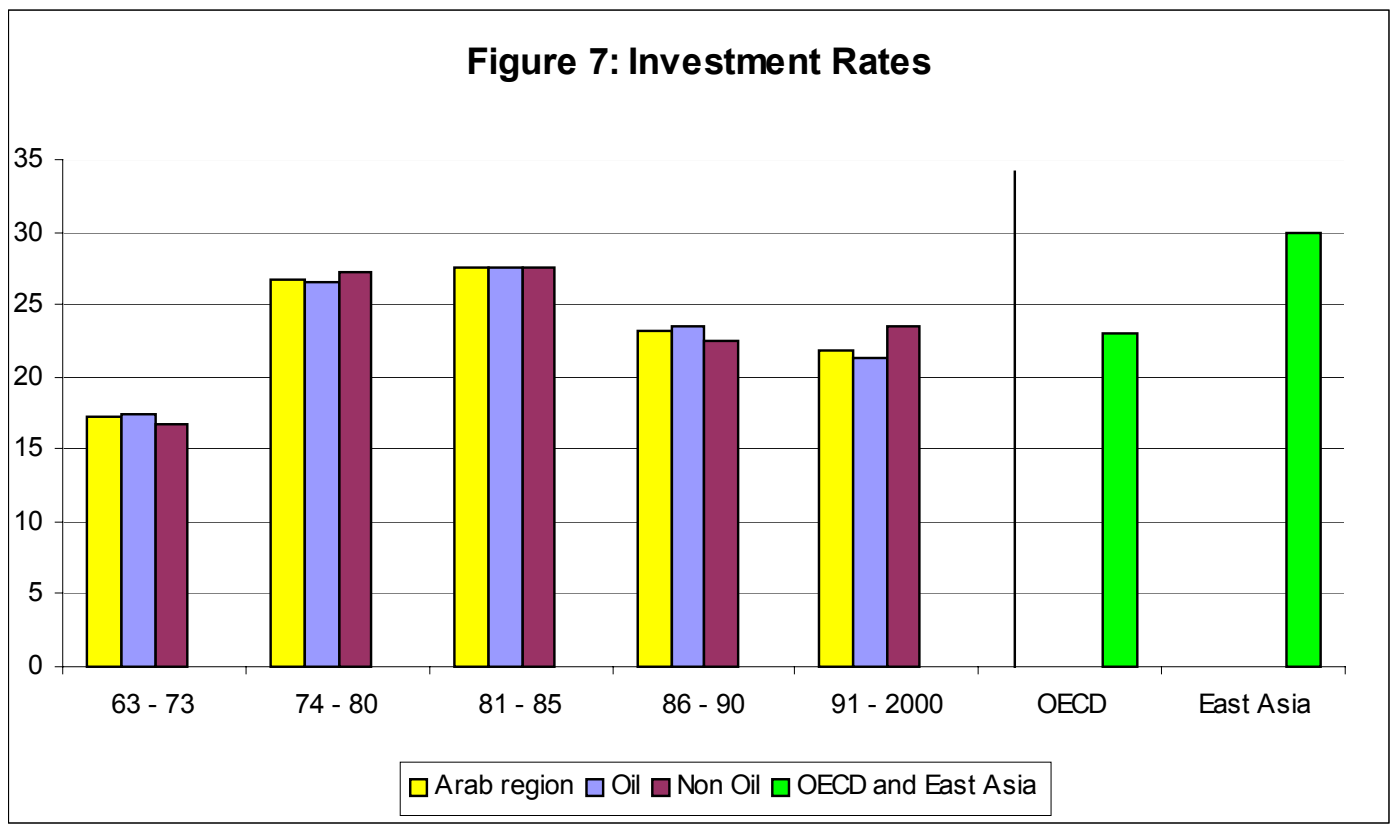

Over time, we see that the investment rate in the Arab world increased substantially from $17 \%$ in the pre-oil shock period to $27 \%$ in the post-oil shock period. The interesting thing is that this rather large shift in the investment rate applies to both oil-producers and non-oil-producers. The puzzling fact is that the investment rate increased again to $28 \%$ during the 1981-1985 period. We say this is puzzling because the growth rate became negative during this period. If the investment rate is a key determinant of the growth rate of an economy, why did the growth rate decline in the 1980s, a time in which the investment rates increased and remained high?

The investment rates declined a little bit during the late 1980s and into the 1990s. Some analysts (UNDP (2002), Bisat et al. (1997)) suggest that this reduction in the investment rate is responsible for the slow growth of the Arab region after 1980. We think that this is not the case for two reasons. First, we note that the reduction in the investment rate occurs five years after the overall growth rate falls dramatically (and even becomes negative). In particular, notice that the investment rate reaches its highest level ( $27 \%$ of GDP) in the 
period 1981-1985, which is precisely the five-year period in which the growth rate was at is lowest level (-2.1\%). One would think that the large investment rates during the early $1980 \mathrm{~s}$ were a response, a consequence to the large growth rates of the 1970s (the Arab countries were trying to invest the proceeds of the good old 70s) rather than the cause of slow growth during that period. Similarly, the reduction in investment rates that followed the horrible first half of the 1980s was a consequence, not a cause, of the terrible growth performance of the first half of the decade.

The second reason is that, despite its small reduction, investment rates remained high for international standards. Granted that the investment rate was not as high as in the miraculous countries of East Asia, but it was certainly comparable to those of the industrial countries of the OECD and far larger than those of the average developing country (see Figure 7). Moreover, investment rates in the Arab world during the late 80s and through the 90s remained higher than they had been in the 1960s, a period in which the region enjoyed much larger growth rates. And if the investment rates were higher in the $90 \mathrm{~s}$ than in the $60 \mathrm{~s}$, why was the growth rate so much lower? Where was all this investment going during the 80s and 90s? Why didn't the large investment effort that was made after 1973 pay off in the form of larger growth rates?

We should point out that the behavior of the Arab countries is not particularly puzzling because empirical growth economists have found that the investment rate is not robustly correlated with growth in a large cross-section of countries. For example, Doppelhoffer et al. (2002) use a new methodology based on Bayesian Model Averaging to test the variables that are robustly correlated with growth and find, perhaps surprisingly, that the investment rate is not one of the successfully robust variables. Similarly, Easterly, Kremer, Prittchet and Summers, (1993) and Easterly and Levine (2001) show that, while the 
investment rate does not change much over time for the majority of countries in the world, the growth rate is highly volatile. If investment rates do not move much across decades but growth rates do, it is not possible for investment to be an important determinant of growth. In fact, this empirical result is partially confirmed by our data for the Arab world: whereas the growth rate falls dramatically after 1973, the investment rate remains relatively constant over the following 27 years. Thus, an initial answer of the question "where has Arab investment gone?" is that we don't know, but this is not especially puzzling because it happens all over the world.

A deeper answer can also be found in the empirical cross-country growth literature: what matters for growth is not the overall level of investment but its quality and efficiency. For example, Sala-i-Martin et al. (2002) find that one of the robust determinants of the rate of economic growth is public investment. Perhaps the surprising fact is that the sign of the partial correlation is... negative!!! In other words, holding constant aggregate investment and various other determinants of growth, the larger the fraction of investment that comes from the public sector, the smaller the growth rate of the country. Although this result might seem puzzling, there are, in fact, some economic explanations for it: Public investment, like all public expenditures, needs to be financed with distortionary taxes, and these tend to hurt economic growth. If public investment is productive, its overall effect on aggregate growth will depend on whether the positive effects on national productivity are larger than the negative effects that arise from the distortionary taxes that need to be raised to finance it. This, of course, is true if public investment is productive. In reality, however, it is not uncommon to see that public investment decisions are made inefficiently or in the wrong sectors. The precise project financed by the public sector could be very productive if chosen efficiently...but it could be quite useless, for example, if the government makes investment 
decisions with the objective of obtaining political or private gains. Notice that unproductive public investment still needs to be financed with distortionary taxes. Thus, when public investment projects in a country are predominantly unproductive, then the their overall effect is to reduce the growth rate.

This discussion is particularly relevant for the Arab world because if we analyze the ratio of private investment to public investment we see that it is unusually low. As seen in Figure 8, for the Arab world as a whole, the ratio is close to 2, that is, private investment is twice as large as public investment. The private/public ratio is slightly larger for non-oil economies than oil economies in the region, but the overall ratio remains well below the levels of OECD economies (with ratios close to 6) or of the rapidly growing East Asian economies (with ratios close to 5 ). ${ }^{5}$

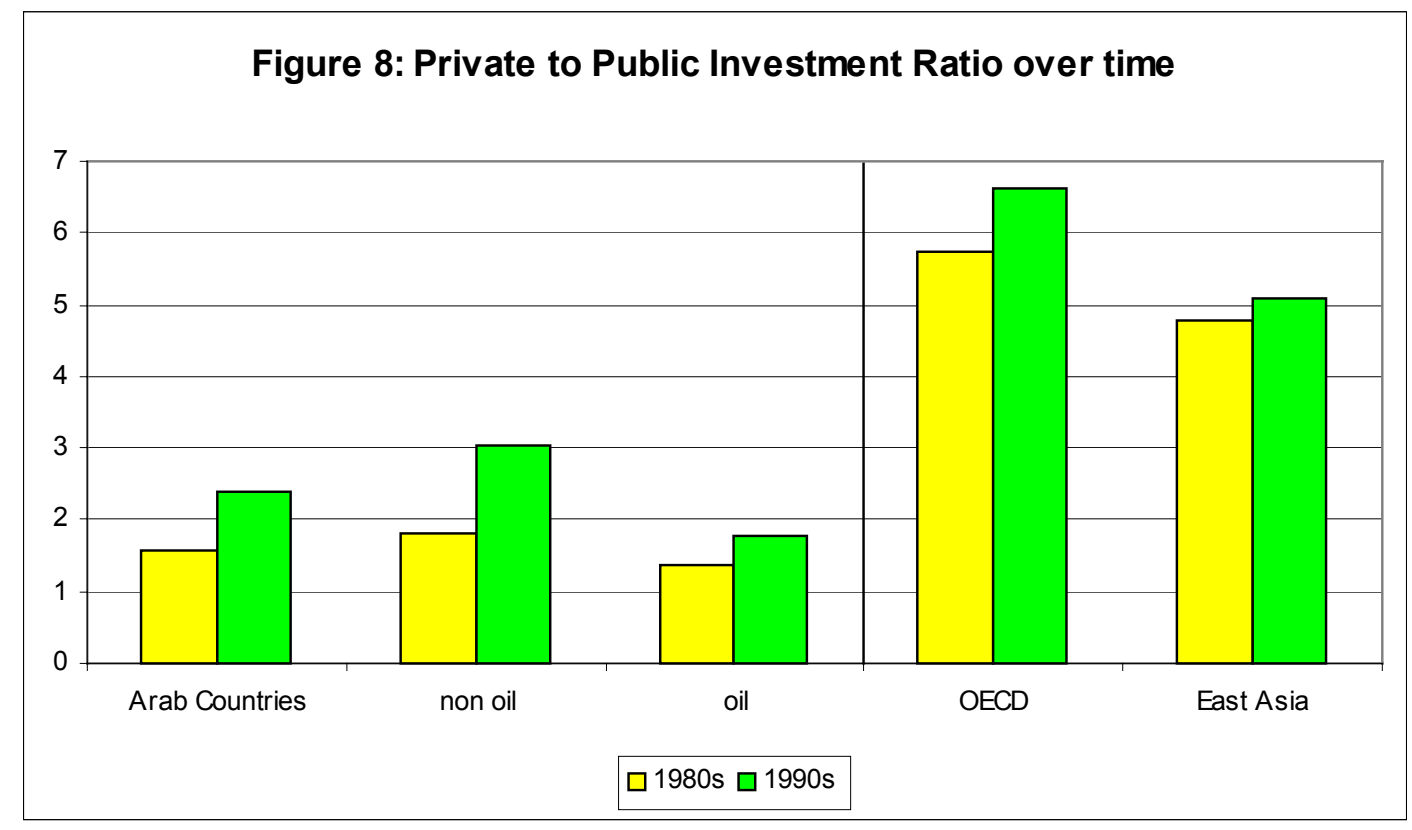

The reforms of the 1990s have moved the Arab economies in the right direction, in the

5 Again, there is substantial heterogeneity within the Arab world: the ratio for Morocco is seven whereas that for Tunisia is four. Both countries' ratios are close to those of the OECD and East Asia. 
sense that the ratio of private to public investment has increased. For the region as a whole, the ratio increased from 1.6 in the $1980 \mathrm{~s}$ to 2.4 in the $1990 \mathrm{~s}$. The non-oil countries were the ones that went further in reforming: the ratio increased from 1.8 to 3.0 whereas the non-oil economies increased from 1.4 to 1.7. As a way of comparison, it is interesting to see that the ratios of OECD economies also increased from 5.7 in the 80 s to 6.6 in the 1990 s. Similarly, the ratios for East Asia increased from 4.8 to 5.1 over the same period. Hence, although reforms in the Arab world have gone in the right direction, they were not nearly large enough to put the private-to-public investment ratios at the levels of OECD or East Asian Economies.

Despite the large investments of the public sector in the Arab world, infrastructures remain alarmingly inefficient. For example, according to the World Bank, the percentage of unsuccessful telephone calls is $35 \%$ in Tunisia, $46 \%$ in Yemen, $50 \%$ in Lebanon, $57 \%$ in Morocco and $60 \%$ in Jordan. Whereas the process of transmission and distribution of electricity suffers losses equivalent to 5\% of output in OECD and East Asian countries, losses in the Arab world amount to $13 \%$. Hardly the numbers on would expect from economically competitive countries. ${ }^{6}$

\section{Inefficient Transmission of Savings to Investment}

Private investment in the Arab world is both insufficient and inefficient. One of the reasons for the insufficiency is that the financial sector does not channel savings properly to productive investment projects. Some of the blame goes to the government and its exceptionally large participation in the financial sector. As is common in most of the developing world, the financial sector in Arab countries plays a smaller role than in rich industrial economies and, perhaps more importantly, it is almost completely dominated by the

6 World Bank (1995). 
banking system. Capital markets are either underdeveloped or non-existent. Most have low levels of trading and very few listed companies. Figure 9 shows three measures of the importance of capital markets: the market capitalization as a percentage of aggregate GDP, the value of stocks traded as percentage of GDP and the turnover ratio. We notice that the three measures show substantial underdevelopment of the Arab world relative to both the industrialized economies of the OECD and the high-growth economies of East Asia. For example, according to the Capital Intelligence Unit (2001), the stock market value of traded companies as a fraction of GDP is 10 times higher in the OECD than in the Arab world and 13 times higher in East Asia. The turnover ratio is 4 and 5 times larger respectively. As an example, at year-end 1999, the Tunis Stock Exchange comprised only 44 companies, of which 13 were banks. Yemen has no stock market. There are two official stock exchanges in the UAE, the Dubai Financial Market (DFM) and the Abu Dabi Securities Market (ADSM). The problem is that the DFM was set up in March 2000 and ADSM in November 2001. The lack of liquid investments has a direct negative effect on productive investment as it makes it difficult for entrepreneurs to raise capital to finance their potentially good ideas. 7 The fact that many of the large companies tend to be either public or in the hands of politically influential individuals has led to low repayment rates and this has contributed to impede the development of efficient bond and capital markets. The low levels of development of capital markets as well as of primary and secondary bond markets forces potential real investors into the hands of the banking system which, as a result, has become immensely powerful (both economically and politically).

7 See Demirguc-Kunt, Asli and Ross Levine for an empirical and theoretical documentation of the negative impact that an underdeveloped financial system may have on growth. 


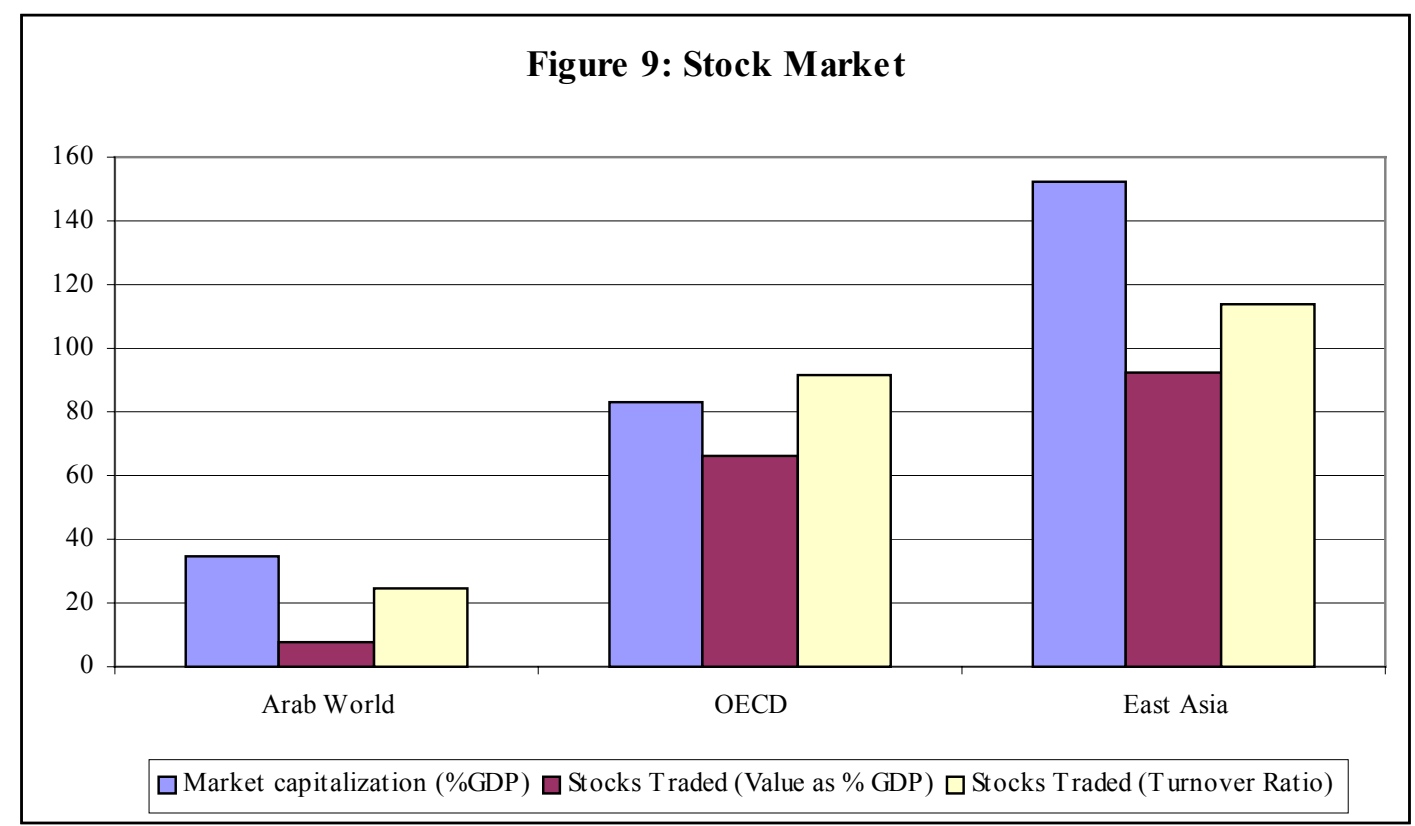

Despite their domination of the financial sector, banks are not sufficiently efficient so as to play the critical role they must play in the process of economic growth and development: lending remains predominantly short-term and trade-related, with very little being directed to long-term productive investments. The lack of competition among banks leads to lack of innovation in lending. Despite recent efforts to liberalize and privatize the banking system, governments have protected the banks from competition by restricting entry at the local and international levels, and this has made them inefficient. In several countries, the state remains the dominant player in the banking system, owning a major proportion of the banks' capital. An important fraction of the state-owned banks' business is the financing of housing at subsidized interest rates, which usually impose significant financial costs to the banks and, therefore, to the state. In some of the countries where the banks are privately owned, public policy tends to select "privileged sectors" that tend to enjoy credit at subsidized interest rates as well as recurrent debt forgiveness. While many countries have freed interests on deposits and lending, the legal failure to enforce collateral rights discourages financial intermediaries 
from lending to small businesses or clients that do not have long borrowing records ... or political connections.

In sum, although the banking system is the most important part of the financial sector, its extraordinarily inefficiency does not lead it to allocate national savings to their most productive uses. Without this proper channeling of savings into productive and efficient investment, economic growth is impossible. Thus, continuing the reform of the banking sector is a necessary process for the Arab world. These reform must include (a) further elimination of abusive and inefficient regulation, (b) opening the financial markets to domestic and foreign entrants in order to promote competition, financial innovation and modernization, (c) strengthening (public or private) supervision to achieve sound corporate governance and accountability, (d) privatization of the remaining state banks, ensuring that the right incentives for sound commercial policies are in place (shifting their commercial operations away from housing-financing at subsidized interest rates to productive long-term investment) and (e) incorporation of the available new technologies that are already changing the nature of the financial sector worldwide.

\section{Inefficient Investment}

Another source of low growth in the Arab world is its reduced overall economic efficiency. One measure of the overall evolution of the efficiency of the economy is the Total Factor Productivity (TFP) growth index. TFP growth measures the growth in the economy that cannot be accounted by the measured increases in capital and labor. In other words, the part of the overall economic growth that cannot be accounted for by increases in physical capital and labor must be accounted by the change in the overall efficiency of capital and labor. Figure 10 shows the evolution of TFP growth for a sample of Arab countries between 
1975 and 2000.8 The numbers are staggeringly low: with the exception of Egypt, Oman, Syria and Tunisia, productivity growth in the Arab world has been negative. That is, the efficiency of the economy has deteriorated markedly.

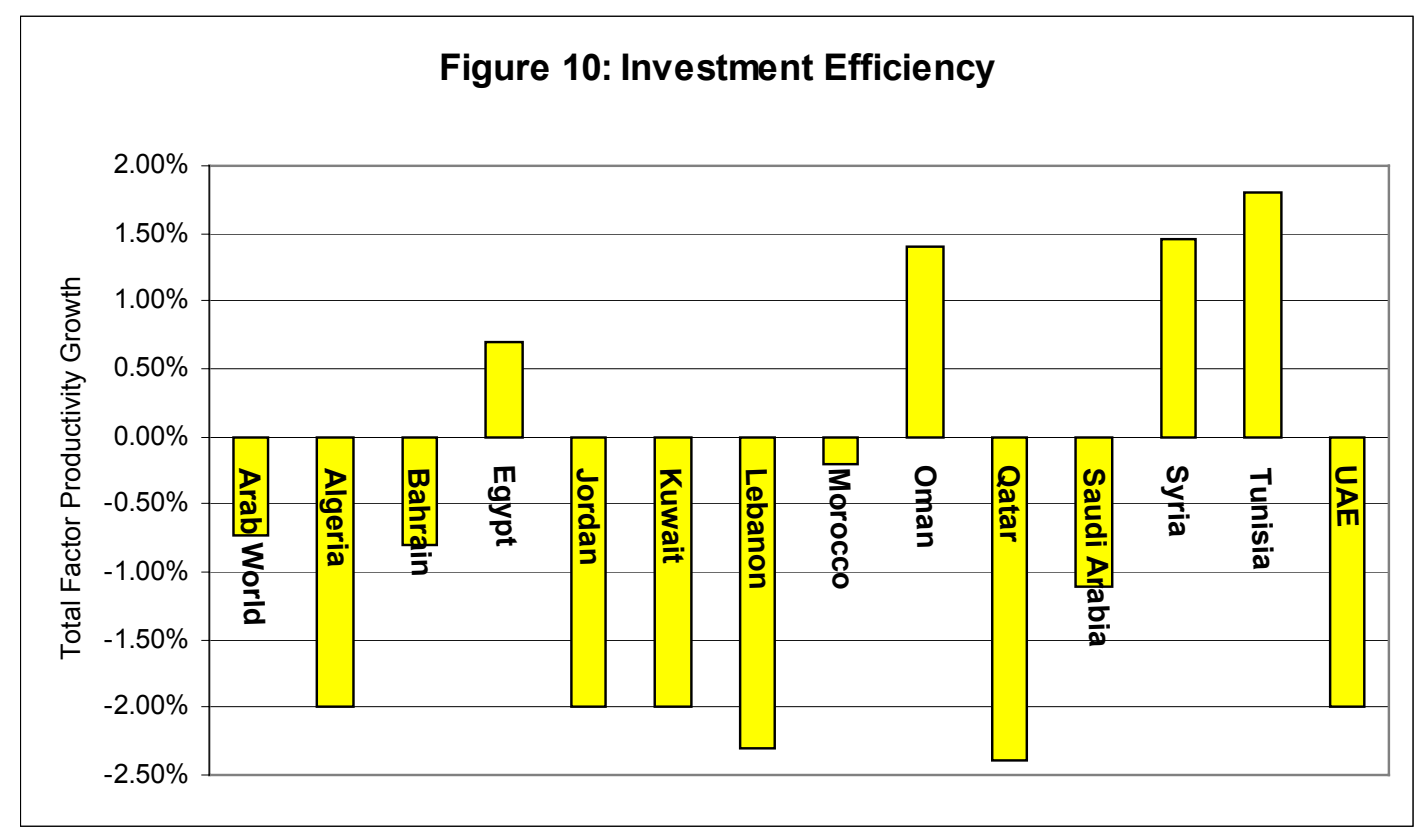

Why is the productivity of investment in the Arab world so low? And why has it declined over time? Again, there is no unique explanation. We will highlight three: political and social instability, a deteriorated business environment due to excessive public intervention and overregulation, and low quality of human capital.

\section{Political Instability}

War, violence, and social conflicts are and have been widespread throughout the Arab World during the period we are considering here. For example, Libya has had constant conflicts with Chad over the Aozou strip and has suffered the U.N. sanctions for supporting

8 The productivity estimates are our own, but they are similar to those estimated by other researchers and analysts (UNDP (2002) and Bisat et al. (1997)) 
terrorism. This is not the optimal political and social environment for productive investment to flourish.

In Algeria, the first round success of the Islamic Salvation Front (FIS) party in December 1991 caused the army to nullify the results and to crack down on the FIS. The FIS reaction resulted in a continuous civil conflict with the state apparatus, with mass assassinations and widespread political violence. FIS's armed arm, the Islamic Salvation Army, disbanded itself in January 2000 and many armed militants surrendered under an amnesty program designed to promote national reconciliation. Nevertheless, residual fighting continues.

Lebanon suffered a devastating 16-year civil war, which ended in 1991. Since then, the country has made progress toward rebuilding its political institutions and regaining its national sovereignty. The Lebanese have conducted several successful elections, most of the militias have been weakened or disbanded, and the Lebanese Armed Forces (LAF) have extended central government authority over about two-thirds of the country. However, Hizballah (the radical Shi'a party) retains its weapons. Syria maintains about 25,000 troops in Lebanon based mainly in Beirut, North Lebanon, and the Bekaa Valley. Syria's troop deployment was legitimized by the Arab League during Lebanon's civil war and in the Ta'if Accord that ended it. Israel's withdrawal from its security zone in southern Lebanon in May of 2000, however, has emboldened some Lebanese Christians and Druze to demand that Syria withdraw its forces as well.

Territorial disputes between Iraq and Iran led to a very costly eight-year war between 1980 and 1988. In August 1990 Iraq seized Kuwait, but was expelled by US-led, United Nations coalition forces during January-February 1991. Following Kuwait's liberation, the UN Security Council required Iraq to destroy all weapons of mass destruction and long-range 
missiles and to allow UN verification inspections. Sanctions remain in effect due to alleged incomplete Iraqi compliance with relevant Security Council's resolutions.

The Israel-PLO Declaration of Principles on Interim Self-Government Arrangements (the DOP), signed in Washington on 13 September 1993, provided for a transitional period not exceeding five years of Palestinian interim self-government in the Gaza Strip and the West Bank. Israel agreed to transfer certain powers and responsibilities to the Palestinian Authority, which includes the Palestinian Legislative Council elected in January 1996, as part of interim self-governing arrangements in the West Bank and Gaza Strip. A transfer of powers and responsibilities for the Gaza Strip and Jericho took place after the May 1994 Cairo Agreement on the Gaza Strip and the Jericho Area. Additional areas of the West Bank followed suit. An intifadah broke out in September 2000; the resulting widespread violence in the West Bank and Gaza Strip, Israel's military response, and instability in the Palestinian Authority are undermining progress toward a permanent settlement and contribute to the deterioration of the business environment that would be necessary to regain the path towards steady economic growth.

The British withdrew from South Yemen (a protectorate they had created in the 19th century around the southern port of Aden) on November 30, 1967. Three years later, the southern government adopted a Marxist orientation. The massive exodus of hundreds of thousands of Yemenis from the south to the north (which had become independent from the Ottoman empire in 1918) contributed to two decades of hostility between the two states. The two countries were formally unified as the Republic of Yemen in May 22, 1990. A southern military bid to break away from the Union was defeated by the north in 1994 .

These are just some examples of political, military, and social conflict that have plagued the Arab world during the last several decades. This kind of instability has direct 
implications on the level of income through destruction of productive capacity, but it also has longer term consequences as it does not contribute to create the business environment that is necessary for any economy to prosper. These conflicts have certainly contributed to deter investment and to slow down the process of economic growth and development in the Arab world.

\section{Business Environment}

The weak business environment of the Arab region acts as another important constraint to the process of economic growth. Of course, the social and military conflicts that we described in the previous section contribute to the continued deterioration of the business environment. But violence is not the only problem. Potential investors in many Arab countries face a suffocating web of complex regulations, licensing, and other institutional distortions which are often unclear and usually inconsistent with the rules that apply in the rest of the world. Most private investors are scared away by such cumbersome process, and this leads to less entry and competition. This lack of competition, in turn, leads to a more inefficient and innovative economic system.

Those investors who are not deterred by such opaque system, play in it at a very high cost. Egyptian entrepreneurs spend close to $35 \%$ of their time solving problems related to government regulation. Even Morocco (a country that has liberalized its economy more than its Arab neighbors) requires more than 20 documents and over six months to register a new business. The easy way around the complicated bureaucratic process is often bribery, local corruption, and unhealthy incest-like relations between family-owned businesses and the political power. Needless to say that this further deteriorates competition and the business environment. 
Privatization and separation of business and politics needs to be a priority in the Arab world. Countries with large and inefficient public sectors (such as Algeria and Egypt) will have to, first, sell off state-owned money-losing enterprises and, second, attract private investment by deregulating and lowering political and institutional barriers of all kinds. The evidence shows that there is no shortage of funding for privatization in the region. But a bottleneck is, again, the inefficient banking system and the small or inexistent debt markets and stock exchanges. Countries with less burdensome public enterprise systems (such as Jordan, Lebanon, Morocco, Tunisia and some Gulf countries) will have to concentrate on the second strategy of reduction of excessive regulation, licensing requirements and bureaucratic barriers that impede the normal process of business investment. Finally, an equitable, wellfunctioning legal system (including an effective judiciary) that supervises the economic process and guarantees transparency and justice is also critical in promoting economic investment and growth.

\section{Human Capital}

Another important explanation for the lack of incentives for private businesses to invest in the Arab world is the low quality of human capital. The economic growth literature has been emphasizing the importance of human capital in the process of economic growth and development. Moreover, it as emphasized the complementarity between human and physical capital investment: if potential investors cannot hire a highly qualified and trained labor force, their investments will not deliver profits. It follows that investment in physical capital will not take place in economies with low-quality human capital.

Despite some improvements over the last two decades, enrollment rates in the Arab world remains well below that of the industrial countries: primary school enrollment remains 
below $85 \%$ (100\% in the OECD), ${ }^{9}$ secondary school enrollment remains below just above $50 \%$ (again close to $100 \%$ in the OECD), and tertiary school enrollment remains below $15 \%$ (over $60 \%$ in the OECD).

But perhaps the most important problem with human capital accumulation in the Arab world is not only the fact that enrollment rates remain below international standards, but the fact that the quality of the education system is low and unconnected to the needs of productive firms. An empirical confirmation of this fact is that the educated in the Arab world suffer from high unemployment rates and declining real wages. More importantly, the education system fails to teach Arab citizens to adapt to a dynamic world of rapid technical change. The Arab educational system does not prepare students for the present world of global knowledge and the information technologies.

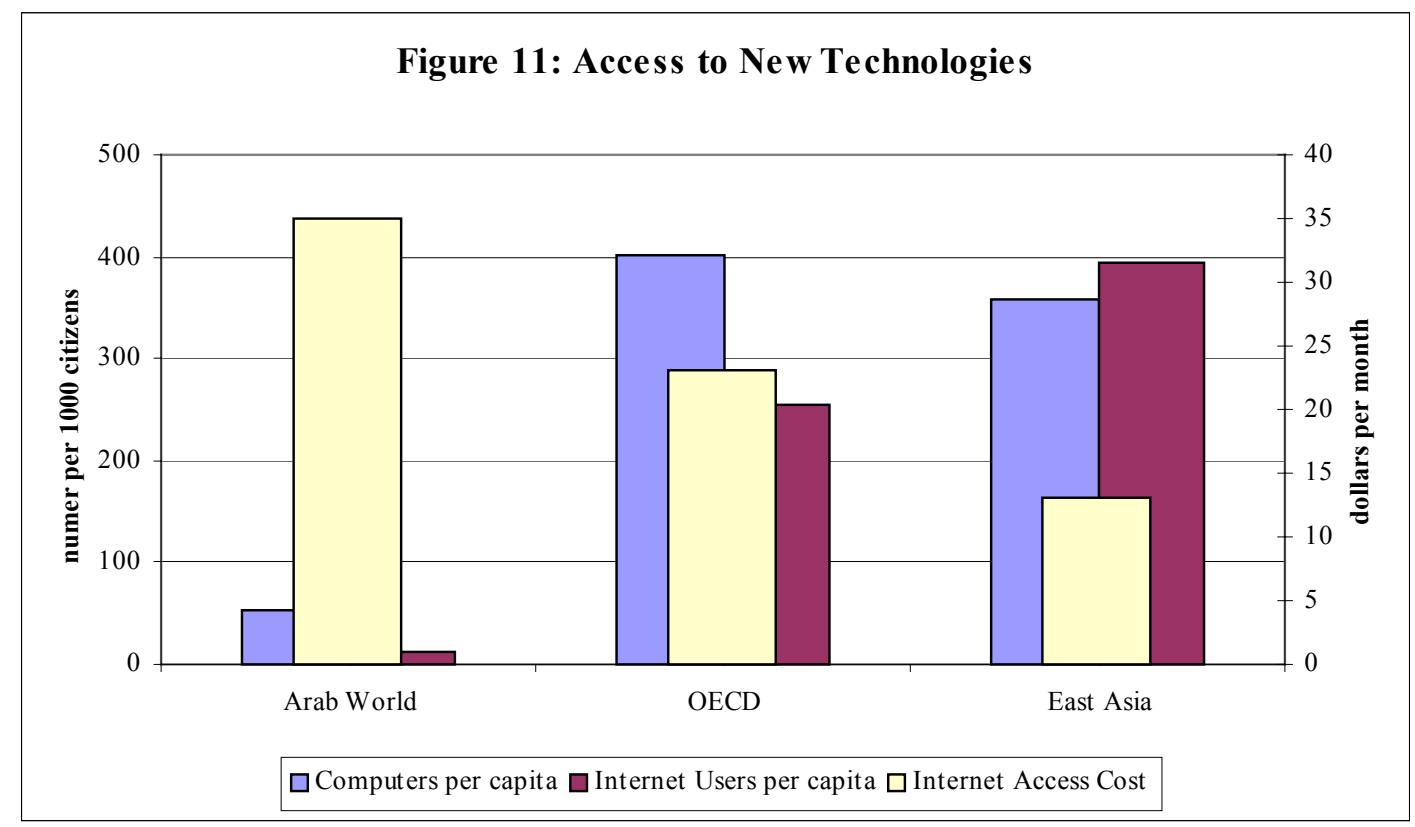

According to ITU (2001), the penetration of both computers and internet access in the Arab world is small relative to that of East Asia and the OECD (see Figure 11). One possible

9 In fact, primary school enrollment ratios in the Arab world are lower than those of the 
reason, of course, is that prices are higher in the Arab world. For example, the ITU reports that off-peak internet access costs close to $\$ 35$ per month in the Arab world whereas the average cost is less than $\$ 23$ in the OECD and about $\$ 13$ in East Asia. The cost in the United States is less than $\$ 7$ whereas in Yemen, internet access costs $\$ 45$, more than 6 times more. Another possibility is, of course, that the people in the Arab world as not as well trained to use new technologies as those of the industrial nations.

The educational system should be reformed to not teach students to "learn things" but to "learn how to learn". Only if the future workers learn to adapt in a changing technological and business environment, firms will feel confident in the human capital of a nation. The reforms must be done by bringing together the education sector, the government and the private business sector. Close coordination between firms and schools and universities is needed if education has to provide useful and productive services to the workers of the future.

The introduction of new technologies provides a unique chance for the Arab world to catch up as it allows to bypass the old problems that have strangled the traditional sectors. In order to take advantage of the opportunities provided by the information technologies, these need to be introduced without the monopolistic and highly distorted structures that characterize the other sectors. Interest groups may make it harder to reform old sectors than to introduce the right structures in new sectors. And this is an opportunity that is not to be missed.

\section{Conclusions}

The Arab world has suffered a 20-year-long growth slowdown. The decline in the investment rate in the region is probably a consequence, not a cause, of this slowdown. 
Investment has remained high for international and historical standards, but this has not translated into larger growth rates. The reason is that what matters for growth is not the quantity of investment but its quality. We argue that there two broad explanations for this "missing growth puzzle". First, too large a fraction of this overall investment has been unproductive public investment. And second, private investment has met a hostile environment in at least three dimensions: (1) excessive political, social, and military conflicts throughout the region, (2) excessive government intervention, protection and regulation suffocates the business environment and makes private investment uncompetitively expensive, and (3) human capital is not adequate. 


\section{References}

Bisat, Amer, Mohammed A. El-Erian, and Thomas Helbing, (1997): "Growth, Investment, and Savings in the Arab Economies", IMF Working Paper.

Capital Intelligence Unit (2001), "National Banking Environment", various issues for Jordan, Oman, Yemen, Bahrain, Qatar, Saudi Arabia, Tunisia, Egypt, United Arab Emirates, Kuwait, Lebanon, Morocco.

Demirguc-Kunt, Asli and Ross Levine eds. (2001), "Financial Structure and Economic Growth: A Cross-Country Comparison of Banks, Markets, and Development", MIT Press, Cambridge, MA, December.

Easterly, William, Michael Kremer, Lant Pritchett, and Lawrence H. Summers. "Good Policy or Good Luck? Country Growth Performance and Temporary Shocks." 1993, Journal of Monetary Economics 32 (3): 459-83.

Easterly, William and Ross Levine "It's Not Factor Accumulation: Stylized Facts and Growth Models" 2001, World Bank Economic Review.

Doppelhoffer, G., R. Miller, and X. Sala-i-Martin,. "The Determinants of Economic Growth: A Bayesian Averaging of Classical Estimates (BACE) Approach", Mimeo Columbia University, August 2002, forthcoming American Economic Review, 2002

Heston, A. R. Summers, and B. Aten, (2001), Penn World Table Version 6.0, Center for International Comparisons at the University of Pennsylvania (CICUP), December.

International Telecommunication Union's (ITU) (2001) "World Telecommunication Development Report, 2001”.

Ravallion, M., Datt, G., and van de Walle, D. "Qualifying Absolute Poverty in the Developing World”, Review of Income and Wealth, 37, 345-361, 1991.

Sala-i-Martin, Xavier, (2002), "Estimating Poverty Rates, Inequality, and the World Distribution of Income from Individual Country Distributions: 1970-1998", mimeograph Columbia University, March.

Solow, R., "A Contribution to the Theory of Economic Growth", Quarterly Journal of Econnomics, February, 1956.

Swan, T. W., "Economic Growth and Capital Accumulation", Economic Record, 1956.

UNDP (2002), “The Arab Human Development Report", United Nations Development Programme, New York, NY.

World Bank (1995), "Claiming the Future: Choosing Prosperity in the Middle East and North Africa”, World Bank Ed., October. 